\begin{tabular}{|c|c|}
\hline $\begin{array}{l}\text { MU\%OVIL } \\
\text { MANAUEMEN } \\
\text { KEWIRAUSAHAAN }\end{array}$ & $\begin{array}{r}\text { p-ISSN 1858-1048 } \\
\text { e-ISSN 2654-9247 } \\
\text { http://ejurnal.stieipwija.ac.id/index.php/jmk } \\
\text { DOI: http://dx.doi.org/10.33370/jmk.v17i2.482 } \\
\text { Jurnal Manajemen Kewirausahaan Vol. 17 No. 02 - Des } 2020 \\
\text { Submit: } 18 \text { Nov 2020; Review: 24 Nov 2020; Publish: } 30 \text { Des } 2020\end{array}$ \\
\hline
\end{tabular}

\title{
PENGARUH KONFLIK, KOMUNIKASI, DAN GAYA KEPEMIMPINAN TERHADAP KINERJA TIM KERJA RSUD CEMPAKA PUTIH
}

\section{(THE EFFECT OF CONFLICT, COMMUNICATION, AND LEADERSHIP STYLES ON THE PERFORMANCE OF THE CEMPAKA PUTIH HOSPITAL TEAM)}

\author{
Oleh: \\ Lenni Ambriani1); Koentari2) \\ lenni.ambriani@gmail.com ${ }^{1)}$; almamita45@gmail.com ${ }^{2)}$ \\ Sekolah Tinggi Ilmu Ekonomi IPWI Jakarta1,2)
}

\begin{abstract}
ABSTRAK
Konflik, komunikasi, dan gaya kepemimpinan merupakan faktor yang relatif besar memengaruhi kinerja tim kerja RSUD Cempaka Putih. Penelitian ini bertujuan untuk mengetahui pengaruh konflik, komunikasi, dan gaya kepemimpinan terhadap kinerja tim kerja RSUD Cempaka Putih. Penelitian dilakukan di RSUD Cempaka Putih dengan mengambil 69 pegawai dari 5 tim kerja sebagai sampel penelitian yang dihitung menggunakna rumus Slovin dari total populasi 219 pegawai pada margin error 10\%. Pengambilan data dilakukan dengan instrumen kuesioner tertutup lima skala penilaian dari sangat tidak setuju sampai dengan sangat setuju. Penelitian dilakukan secara kuantitatif yaitu dengan mendeskripsikan data penelitian dan dilakukan analisis inferensi. Analisis regresi ganda digunakan sebagai alat analisis sedangkan pengujian hipotesis dilakukan dengan uji-t dan uji-F. Berdasarkan hasil temuan tersebut maka untuk meningkatkan kinerja tim kerja disarankan agar dilakukan upaya untuk memperbaiki penanganan konflik, meningkatkan komunikasi dan memperbaiki gaya kepemimpinan.
\end{abstract}

Kata kunci: Gaya Kepemimpinan; Kinerja Tim; Komunikasi; Konflik

\begin{abstract}
Conflict, communication, and leadership style are relatively large factors affecting the work team performance of Cempaka Putih Hospital. This study aims to determine the effect of conflict, communication, and leadership style on the work team performance of Cempaka Putih Hospital. The research was conducted at Cempaka Putih Hospital by taking 69 employees from 5 work teams as the research sample which was calculated using the Slovin formula from a total population of 219 employees at a margin of error of 10\%. Data were collected using a closed questionnaire instrument with five rating scales from strongly disagree to strongly agree. The research was conducted quantitatively, namely by describing the research data and conducting inference analysis. Multiple regression analysis is used as an analysis tool while hypothesis testing is done by $t$-test and F-test. Based on these findings, to improve the work team's performance, it is recommended that efforts be made to improve conflict handling, improve communication and improve leadership styles.
\end{abstract}

Keywords: Communication; Conflict; Leadership Style; Team Performance

Jurnal Manajemen Kewirausahaan Vol. 17 No. 02 - Desember 2020

LP2M Sekolah Tinggi Ilmu Ekonomi IPWI Jakarta 


\section{PENDAHULUAN}

Dalam organisasi dengan konsep modern saat ini, sebuah tim diperlukan untuk mencapai tujuan dan hasil yang lebih efektif karena pekerjaan akan diselesaikan bersama-sama sesuai dengan kemampuan dan tanggung jawab masing-masing. Beban kerja dapat dibagi kepada orang yang tepat sehingga tujuan dapat dicapai dengan maksimal. Karena itu karyawan saat ini dituntut untuk mampu bekerja sama dalam tim dengan tujuan mampu menciptakan kekompakan dalam bekerja sesuai dengan hasil dan waktu yang telah ditetapkan. Kerjasama tim adalah salah satu aspek yang mendukung efektivitas pekerjaan dalam organisasi. Sebuah tim yang kuat akan menjaga hubungan yang erat satu sama lain seperti sebuah keluarga yang akan selalu berusaha untuk meningkatkan pencapaian tim dan memberikan dampak besar yang dapat menguntungkan organisasi.

Menurut Amir (2017), konflik yang buruk mengganggu kerekatan tim, information sharing, pengambilan keputusan, dan kesejahteraan karyawan (melalui meningkatnya stres dan rendahnya kepuasan kerja). Persepsi juga terganggu dan meningkatkan politik organisasi. Di sisi lain, telah lama orang mendorong pandangan bahwa konflik dapat juga bermanfaat. Konflik pada dasarnya dapat dioptimalkan. Dalam tingkatan tertentu, konflik bisa memberikan manfaat pada organisasi dan karyawan. Meskipun manfaat juga akan sulit dicapai kalau tingkatannya begitu tinggi. Konflik memberikan energi orang yang membahas sesuatu dan melakukan evaluasi atas alternatif. Dalam sebuah tim, orang bisa belajar antara satu sama lain, memahami masalah sesungguhnya yang perlu diatasi. Solusi kreatif bisa hadir dengan adanya konflik.

Komunikasi dapat terjadi apabila ada kesamaan makna antara penyampai pesan dan orang yang menerima pesan. Kurang efektifnya proses komunikasi akan membuat kesalahpahaman dan mengakibatkan perselisihan atau menimbulkan suatu konflik sehingga tujuan akan terkendala karena kurangnya kerjasama antar anggota tim.

Amir (2017) menyatakan dalam kesimpulannya, komunikasi merupakan salah satu aspek yang kerap menjadi sumber konflik. Memastikan cara dan isi komunikasi yang baik dapat meminimalkan potensi konflik. Begitupula dengan mengetahui pola orang menangani konflik akan membuat kita dapat merespons dengan baik sehingga mencapai solusi yang optimal.

Gaya kepemimpinan adalah salah satu faktor yang menentukan keberhasilan pemimpin dalam mengarahkan anggota tim dalam mencapai tujuan. Hal ini juga akan mencerminkan sifat dan kepribadian pemimpin itu sendiri. Kepemimpinan terjadi karena faktor saling mempengaruhi dan mengarahkan orang lain untuk bertindak, meniru, dan mengikuti perintah seseorang.

Menurut Wibowo (2014), peran seorang manajer di dalam memimpin bawahannya, peran seorang team leader dalam menggerakkan kerja sama anggota tim, dan peran seorang pemimpin dalam mengarahkan dan menggerakkan sumber daya manusia dalam organisasi untuk mencapai tujuan, sangat menentukan bagi pencapaian kinerja dan terjadinya kesenjangan kinerja.

RSUD Cempaka Putih merupakan rumah sakit umum daerah yang melayani pasien baik dari Jakarta Pusat maupun dari luar daerah dengan dukungan dokter ahli dan perawat berkualitas. Karyawan dituntut untuk multi tasking dan mudah beradaptasi dengan berbagai unit kerja. Hal ini tentu harus didukung dengan komunikasi yang baik dalam menghadapi konflik yang terjadi baik dalam skala kecil maupun besar. Beberapa konflik diselesaikan dengan musyawarah yang baik antara atasan dengan anggota tim/unit kerja. Konflik yang membutuhkan persetujuan dan keputusan dari pimpinan tertinggi sangat jarang ditemui. Rapat umum yang diadakan sebulan sekali menjadi salah satu strategi dalam pengawasan kinerja masing-masing unit maupun karyawan. Gaya kepemimpinan masing-masing 
kepala unit hampir seluruhnya menganut gaya kepemimpinan demokrasi di mana kepala unit menganggap anggota unitnya sebagai partner kerja.

Berdasarkan uraian di atas dapat disimpulkan pentingnya konflik dan komunikasi dalam keberhasilan suatu tim kerja, juga pentingnya pengaruh seorang pemimpin dalam mengarahkan bawahan atau anggota timnya dalam mencapai tujuan tim.

\section{TUJUAN PENELITIAN}

Tujuan umum penelitian ini adalah untuk mengetahui pengaruh konflik, komunikasi, dan gaya kepemimpinan terhadap kinerja tim kerja di RSUD Cempaka Putih.

\section{TELAAH LITERATUR DAN PENGEMBANGAN HIPOTESIS Kinerja Tim Kerja}

Dalam suatu organisasi, kinerja tim akan lebih unggul daripada kinerja individu saat tugas yang dilakukan mengharuskan untuk memiliki keterampilan ganda dengan hasil yang cukup besar.

Menurut Tjosvold et al. (2002) dalam Wartini (2015), kinerja tim sesungguhnya dinilai dari kemampuan keharmonisan setiap individu karyawan dalam berbagi tugas pokok dan fungsi pekerjaan kepada rekan kerja lainnya, adanya keterbukaan melalui pemanfaatan komunikasi antar rekan kerja, mempertimbangkan efektivitas dan efisiensi kerja, serta mau menerima metode-metode baru dalam penyelesaian pekerjaan.

Beberapa penjelasan di atas dapat terlihat bahwa selain penilaian kinerja masing-masing individu, penilaian dalam tim seperti komunikasi, kepemimpinan dan kontribusi dalam tim juga menjadi suatu penilaian yang juga diperhatikan dalam organisasi.

\section{Konflik}

Karyawan dan organisasi harus dapat bekerja sama dalam menangani konflik yang ada dalam pekerjaan.
Menurut Fahmi (2016), adapun pengertian konflik adalah sebuah persepsi yang berbeda dalam melihat suatu situasi dan kondisi yang selanjutnya teraplikasi dalam bentuk aksi-aksi sehingga telah menimbulkan pertentangan dengan pihak-pihak tertentu.

Menurut Sule dan Priansa (2018), secara umum ada tiga pemicu utama munculnya konflik, yaitu komunikasi, struktur organisasi, dan faktor manusia.

Sementara menurut Rachman (2016), penyebab timbulnya konflik dapat dikelompokkan dari faktor-faktor organisasi dan faktor-faktor antarpribadi.

Dari beberapa pernyataan di atas dapat disimpulkan bahwa konflik merupakan suatu kondisi yang saling bertentangan dan menimbulkan adanya potensi pertikaian antara satu dan lainnya. Tidak selamanya konflik harus menimbulkan perseteruan. Konflik dapat menimbulkan inovasi dan ide-ide baru terhadap pekerjaan.

\section{Komunikasi}

Konsep manusia sebagai makhluk sosial memang paling pas untuk dijadikan penggambaran dari suatu kerja sama kelompok. Seperti yang dinyatakan oleh Rachmawati (2017), sekadar mampu dalam berkomunikasi saja tidaklah cukup. Apalagi jika sudah terlibat dalam sebuah kelompok. Untuk dapat bekerja dalam sebuah teamwork, keterampilan komunikasi adalah faktor yang teramat penting. Keterampilan ini berupa mendengarkan, memahami, dan merefleksikan.

Chandra (2018) menyatakan, harmoni dalam teamwork sangat membutuhkan komunikasi yang efektif. Efektifnya sebuah komunikasi adalah cara yang paling tepat untuk menumbuhkan kesadaran dan pengertian (cognition) orang-orang yang akan kita ajak dalam mewujudkan harmoni dalam teamwork. Bahkan untuk mengimplementasikan $3 \mathrm{i}$ (inspiring, influence, impact) dan 3P (parahute, pacemaker, peacemaker) komunikasi adalah basic-nya. 
Hal ini menunjukkan bahwa dengan komunikasi yang efektif, karyawan dan organisasi dapat mencari solusi atas masalah yang dihadapi termasuk dalam proses evaluasi kinerja yang saat ini telah dicapai dan yang akan dicapai pada masa mendatang. Interaksi yang terjadi dalam tim juga dapat menciptakan iklim kerja yang baik untuk organisasi.

\section{Gaya Kepemimpinan}

Menurut Zainal et al. (2017), gaya kepemimpinan adalah sekumpulan ciri yang digunakan pimpinan untuk memengaruhi bawahan agar sasaran organisasi tercapai atau dapat pula dikatakan bahwa gaya kepemimpinan adalah pola perilaku dan strategi yang disukai dan sering diterapkan oleh seorang pemimpin. Pada 1960-an berkembang teori kepemimpinan dinamakan "pola manajerial". Kepemimpinan dipengaruhi oleh dua perhatian manajerial yang mendasar, yaitu perhatian terhadap produksi/tugas dan perhatian terhadap manusia. Menurut teori ini ada empat gaya dasar kepemimpinan: (1) gaya manajemen tugas, pemimpin menunjukkan perhatian tinggi terhadap produksi, tetapi perhatian rendah terhadap manusia, (2) gaya manajemen country club, pemimpin memperlihatkan perhatian yang tinggi terhadap manusia, tetapi perhatian rendah terhadap produksi, (3) gaya manajemen miskin, pemimpin tidak terlalu menunjukkan perhatian, baik terhadap produksi maupun manusia, (4) gaya manajemen tim, pemimpin menunjukkan perhatian tinggi baik terhadap produksi maupun terhadap manusia. Menurut teori ini, gaya manajemen tim, yang pada dasarnya sama dengan gaya demokratis merupakan gaya kepemimpinan yang terbaik dalam segala situasi.

Gaya kepemimpinan yang tepat akan membuat karyawan dapat mengikuti arahannya dan dengan sendirinya berkontribusi lebih besar untuk mencapai tujuan secara bersama-sama.

\section{Kerangka Pemikiran}

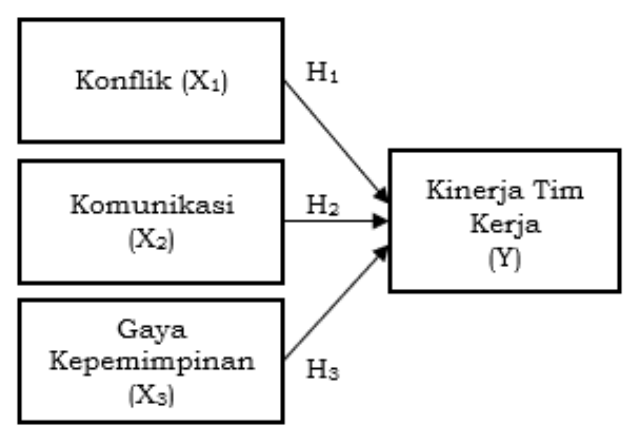

Gambar 1. Kerangka Pemikiran

H1: konflik berpengaruh signifikan terhadap kinerja tim kerja.

H2: komunikasi berpengaruh signifikan terhadap kinerja tim kerja.

H3: gaya kepemimpinan berpengaruh signifikan terhadap kinerja tim kerja.

\section{METODE PENELITIAN}

Dalam penelitian ini sampel yang digunakan dari jumlah populasi 219 orang adalah sebesar 69 sampel dan 5unit kerja dengan perhitungan rumus slovin. Metode pengumpulan data dalam penelitian ini adalah wawancara, studi pustaka, dan kuesioner dengan menggunakan Skala Likert.

Supaya diperoleh data penelitian yang valid dan reliabel maka sebelum instrumen kuesioner tersebut diberikan pada responden perlu dilakukan uji validitas dan reabilitasnya terlebih dahulu. Instrumen yang tidak valid dan reliabel bila digunakan untuk mengumpulkan data, akan menghasilkan data yang tidak valid dan tidak reliabel pula. Analisis selanjutnya dilakukan dengan Reliability Analysis menggunakan software SPSS 24.

\section{HASIL DAN PEMBAHASAN}

Pengukuran variabel penelitian dilakukan dengan menggunakan kuesioner yang dikembangkan dari indikator pada masing-masing variabel penelitian. Dari hasil uji validitas terhadap masing-masing variabel penelitian ditemukan bahwa tidak seluruh item pernyataan pada setiap variabel telah valid. Melalui uji reliabilitas 
ditemukan bahwa seluruh butir pernyataan yang telah valid pada masing-masing variabel penelitian dapat dibuktikan reliabilitasnya. Analisis deskriptif terhadap variabel penelitian menghasilkan temuan yang relatif sama untuk semua variabel penelitian dimana seluruh variable cenderung baik.

Hasil analisis regresi linier ganda adalah sebagai berikut:

Tabel 1. Model Summary

\begin{tabular}{|l|c|r|r|r|}
\hline Model & $\mathrm{R}$ & R Square & $\begin{array}{c}\text { Adjusted } \\
\text { R Square }\end{array}$ & $\begin{array}{c}\text { Std. Error of } \\
\text { the Estimate }\end{array}$ \\
\hline 1 & $.668^{\mathrm{a}}$ & .447 & .421 & 2.602 \\
\hline
\end{tabular}

Sumber: Data penelitian yang diolah, 2020

Dari tabel tersebut di atas diperoleh nilai koefisien determinasi ganda (Adjusted $\mathrm{R}^{2}$ ) sebesar 0.421. Nilai $\mathrm{R}^{2}=$ 0.447 menunjukkan bahwa X1 (konflik), $\mathrm{X} 2$ (komunikasi), dan $\mathrm{X} 3$ (gaya kepemimpinan) dalam model secara bersama-sama mampu menjelaskan $44.7 \%$ variabel $\mathrm{Y}$ sedangkan $55.3 \%$ variabel Y lainnya dijelaskan oleh variabel lain yang tidak diteliti.

Hasil analisis berikutnya berupa tabel anova yang digunakan untuk menguji hipotesis pengaruh konflik, komunikasi, dan gaya kepemimpinan terhadap kinerja tim kerja.

Tabel 2. ANOVA ${ }^{b}$

\begin{tabular}{|c|c|c|c|c|c|}
\hline Model & $\begin{array}{c}\text { Sum of } \\
\text { Squares }\end{array}$ & $\mathrm{df}$ & $\begin{array}{c}\text { Mean } \\
\text { Square }\end{array}$ & $\mathrm{F}$ & Sig. \\
\hline 1 Regression & 355.262 & 3 & 118.421 & 17.495 & $.000^{\mathrm{b}}$ \\
Residual & 439.984 & 65 & 6.769 & & \\
Total & 795.246 & 68 & & & \\
\hline
\end{tabular}

a. Dependent Variable: $Y$

b. Predictors: (Constant), X3, X2, X1

Sumber: Data penelitian yang diolah, 2020

Karena nilai $\rho \neq 0$ dan probabilitas $F$ hitung lebih kecil daripada taraf uji penelitian (sig $\mathrm{F}<\mathrm{a}$ atau $0.000<0.05$ ), maka Ho ditolak dan Ha diterima yang berarti model persamaan regresi ganda pengaruh konflik (X1), komunikasi (X2), dan gaya kepemimpinan (X3) terhadap kinerja tim kerja $(\mathrm{Y})$ adalah layak.

Analisis regresi linier ganda juga menghasilkan tabel koefisien yang menunjukkan pengaruh parsial konflik, komunikasi, dan gaya kepemimpinan terhadap kinerja tim kerja yaitu sebagai berikut:

Tabel 3. Coefficients ${ }^{a}$

\begin{tabular}{|l|r|r|r|r|l|}
\hline \multirow{2}{*}{ Model } & \multicolumn{2}{|c|}{$\begin{array}{c}\text { Standar } \\
\text { Unstandardized } \\
\text { dized } \\
\text { Coeffici } \\
\text { ents }\end{array}$} & $\mathrm{t}$ & Sig. \\
\cline { 2 - 6 } & \multicolumn{1}{|c|}{$\mathrm{B}$} & $\begin{array}{c}\text { Std. } \\
\text { Error }\end{array}$ & Beta & & \\
\hline 1 (Constant) & 10.941 & 4.614 & & 2.372 & .021 \\
X1 & .298 & .105 & .300 & 2.833 & .006 \\
X2 & .475 & .092 & .512 & 5.175 & .000 \\
X3 & -.057 & .119 & -.048 & -.477 & .635 \\
\hline
\end{tabular}

Sumber: Data penelitian yang diolah, 2020

Dari tabel di atas dapat disusun model persamaan regresi linier ganda berdasar kolom B. Model persamaan regresi linier ganda hasil penelitian adalah sebagai berikut:

$\mathrm{Y}=10.941+0.298 \mathrm{X} 1+0.475 \mathrm{X} 2+-0.057 \mathrm{X} 3$.

$(0.006) \quad(0.000) \quad(0.635)$

Model persamaan regresi linier ganda hasil analisis tersebut dapat diartikan: 1) Nilai konstanta sebesar $\mathrm{a}=$ 10.941 , artinya bahwa jika $\mathrm{X}_{1}, \mathrm{X}_{2}$, dan $\mathrm{X}_{3}$ dianggap konstan maka $Y$ akan bernilai positif. 2) Nilai koefisien regresi $X_{1}$ sebesar $b_{1}=0.298$ dan sig. $t=0.006<$ 0.05 menunjukkan bahwa $\mathrm{X}_{1}$ berpengaruh terhadap $\mathrm{Y}$ dengan arah positif dan signifikan. 3) Nilai koefisien regresi $\mathrm{X}_{2}$ sebesar $\mathrm{b}_{2}=0.475$ dan sig. $\mathrm{t}=$ $0.000<0.05$ menunjukkan bahwa $\mathrm{X}_{2}$ berpengaruh terhadap $\mathrm{Y}$ dengan arah positif dan signifikan. 4) Nilai koefisien regresi $\mathrm{X}_{3}$ sebesar $\mathrm{b}_{2}=-0.057$ dan sig. $\mathrm{t}=$ $0.635>0.05$ menunjukkan bahwa X3 berpengaruh terhadap $\mathrm{Y}$ dengan arah negatif dan tidak signifikan.

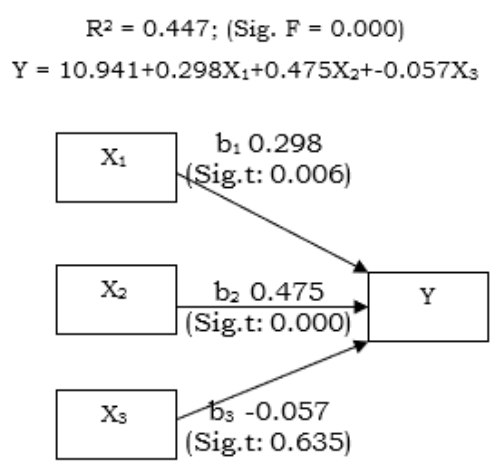

Gambar 2. Hasil Analisis 


\section{KESIMPULAN \\ Kesimpulan}

Konflik memiliki pengaruh positif dan signifikan terhadap kinerja tim kerja. Komunikasi memiliki pengaruh positif dan signifikan terhadap kinerja tim kerja sedangkan gaya kepemimpinan memiliki pengaruh negatif dan tidak signifikan terhadap kinerja tim kerja RSUD Cempaka Putih Jakarta.

\section{Saran}

Berdasarkan kesimpulan di atas, saran yang dapat dijadikan pertimbangan bagi pihak instansi diharapkan untuk tetap menjalin komunikasi yang baik di antara anggota tim di RSUD Cempaka Putih baik secara horizontal, vertikal, dan dengan anggota tim lain dalam rangka pelaksanaan tugas masing-masing. Selain itu, konflik yang terjadi di ruang lingkup pekerjaan terutama di dalam tim juga harus diperhatikan dan ditangani dengan baik, karena meskipun tidak selamanya konflik berkonotasi buruk namun akan berakibat merugikan jika penanganan dilakukan dengan cara yang salah. Walaupun dalam penelitian ini gaya kepemimpinan tidak berpengaruh terhadap kinerja tim kerja, namun hal ini juga harus mendapat perhatian khusus bagi pihak instansi, karena terciptanya sebuah tim yang solid dan efektif adalah dari pemimpin juga.

\section{DAFTAR PUSTAKA}

Amir, M. T. (2017). Perilaku Organisasi. Jakarta: PrenadaMedia.

Chandra, M. (2018). 1 Team 1 Goal. Jakarta: Kompas Gramedia.

Fahmi, I. (2016). Pengantar Manajemen Sumber Daya Manusia: Konsep \& Kinerja. Jakarta: Mitra Wacana Media.

Rachman, T. (2016). Manajemen Sumber Daya Manusia Perusahaan. Bogor: Penerbit Ghalia Indonesia.

Rachmawati, I. (2017). All About Teamwork. Yogyakarta: Psikologi corner.

Sule, E. T., \& Priansa, D. J. (2018). Kepemimpinan dan Perilaku Organisasi (Membangun Organisasi
Unggul di Era Perubahan). Bandung: Refika Aditama.

Wartini, Sri. (2015). Strategi Manajemen Konflik sebagai Upaya Meningkatkan Kinerja Teamwork Tenaga Kependidikan. Jurnal Manajemen dan Organisasi, 6(1), 65-73.

Wibowo. (2014). Manajemen Kinerja Edisi Keempat. Jakarta: RajaGrafindo Persada.

Zainal, V. R., \& Hadad, M. D; Ramly, M. (2017). Kepemimpinan dan Perilaku Organisasi, Edisi Keempat. Jakarta: Rajawali Pers. 